\title{
When Bioequivalence in Healthy Volunteers May not Translate to Bioequivalence in Patients: Differential Effects of Increased Gastric pH on the Pharmacokinetics of Levothyroxine Capsules and Tablets
}

\author{
Corinne Seng Yue ${ }^{1}$, Salvatore Benvenga ${ }^{2}$, Claudia Scarsi $^{3}$, Luca Loprete ${ }^{4}$ and Murray P. Ducharme ${ }^{1,5}$ \\ ${ }^{1 .}$ Learn and Confirm Inc., St-Laurent, Quebec, Canada. ${ }^{2 .}$ University Hospital, Interdepartmental Program on Molecular and \\ Clinical Endocrinology \& Women's Endocrine Health, Messina, Italy. ${ }^{3 .}$ IBSA Institut Biochimique SA, Switzerland. ${ }^{4}$ \\ CROSS Metrics S.A., via F.A. Giorgioli 14, 6864 Arzo, Switzerland. ${ }^{5}$. Faculté de Pharmacie, University of Montreal, \\ Montreal, Quebec, Canada
}

Received, August 5, 2015; Revised, November 6, 2015; Accepted, November 21, 2015; Published, November $23,2015$.

\begin{abstract}
Purpose: Clinical studies have suggested that proton pump inhibitors may decrease levothyroxine absorption and an in vitro study suggested that the effect of $\mathrm{pH}$ on dissolution may differ with formulation. To determine the impact of formulation on the pharmacokinetics of levothyroxine in altered gastric $\mathrm{pH}$ conditions, this study compared the pharmacokinetics of levothyroxine capsules and tablets, two formulations deemed bioequivalent in healthy volunteers under fasting conditions, when taken with or without esomeprazole. Methods: Two clinical studies were conducted in healthy volunteers given single dose levothyroxine $(600 \mu \mathrm{g})$ with a 45-day washout period. In Study 1 (parallel-design/two-way crossover), 16 subjects received either levothyroxine capsules or tablets, each group with or without prior administration of intravenous esomeprazole (maximum dose of $80 \mathrm{mg}$ ). In Study 2 (two-way crossover), 16 subjects received both capsules or tablets after intravenous esomeprazole. Blood samples were collected pre-dose and up to 24 hours post-dose. Baselineadjusted pharmacokinetic parameters were calculated: $\mathrm{C}_{\max }$ (maximal concentration), $\mathrm{T}_{\max }$ (time to $\mathrm{C}_{\max }$ ), $A \mathrm{AUC}_{0-\mathrm{t}}$ (area under the concentration-time curve from 0 to the last detectable concentration), $\mathrm{AUC}_{0-6}$ and $\mathrm{AUC}_{0-12}$ (areas under the curve from 0 to 6 and 12 hours, respectively). Analyses of variance were conducted to compare $\ln$ transformed $\mathrm{C}_{\max }$ and AUC. Non-parametric $\mathrm{T}_{\max }$ analyses were done. Results: In Study 1, esomeprazole caused a greater decrease in overall levothyroxine exposure of tablets vs. capsules $\left(13 \%\right.$ vs $6 \%$ for $\mathrm{C}_{\max }, 18 \%$ vs. $14 \%$ for $\mathrm{AUC}_{0-6}, 17 \%$ vs. $5 \%$ for $\mathrm{AUC}_{0-12}$ and $10 \%$ vs. $8 \%$ for $\mathrm{AUC}_{0-\mathrm{t}}$ ). In Study 2 esomeprazole administration resulted in a $16 \%$ smaller levothyroxine exposure with tablets vs. capsules. No statistically significant differences in $\mathrm{T}_{\max }$ were found. Conclusions: Although both formulations are considered "bioequivalent" in healthy volunteers, they may not necessarily be bioequivalent in patients with impaired gastric $\mathrm{pH}$ conditions. Levothyroxine capsules may therefore be more appropriate for patients with decreased gastric acidity.
\end{abstract}

This article is open to POST-PUBLICATION REVIEW. Registered readers (see "For Readers") may comment by clicking on ABSTRACT on the issue's contents page.

\section{INTRODUCTION}

Levothyroxine (LT4) is a cornerstone in the treatment of hypothyroidism (1), a disorder that affects 0.6 to 12 out of every 1000 women across Europe, Japan and the U.S. and every 1.3 to 4 out of 1000 men $(2,3)$. Levothyroxine supplements exist in various forms, ranging from oral solutions to tablets. More recently, a soft gelatin capsule composed of an outer gelatin shell and a viscous fill has been developed by IBSA Institut Biochimique SA and proved to be bioequivalent under fasting conditions in healthy volunteers compared to already commercialized reference tablets (4).
As reviewed in detail recently (5-7) the oral absorption of levothyroxine can be impaired by endogenous and exogenous causes, the latter including food, coffee or drugs. Proton pump inhibitors (PPI) by modifying gastric $\mathrm{pH}$ are known to interfere with the absorption of several drugs either by increasing or decreasing their bioavailability (e.g. antiretrovirals, ketoconazole, iron salts, erlotinib, mycophenolate mofetil, digoxin) (8) and have also been shown to influence

\footnotetext{
Corresponding Author: Murray P. Ducharme, Learn and Confirm Inc. 3630 Bois Franc, St-Laurent, Quebec, Canada. Email: murray.ducharme@learnandconfirm.ca
} 
the absorption of levothyroxine. Centanni and colleagues demonstrated that normal gastric acid secretion plays a key role in the absorption of thyroxine (9). In their study, euthyroid patients suffering from nontoxic multinodular goiter who were diagnosed with impaired gastric acid secretion were compared to a cohort of nontoxic multinodular goiter patients who did not have impaired gastric secretion. Results showed that patients with impaired gastric acid secretion required a higher dose of levothyroxine in order to achieve similar suppression of thyrotropin (thyroid stimulating hormone or TSH). Similar results were seen in a subset of 10 patients who were treated with omeprazole. In the presence of omeprazole, the levothyroxine dose had to be increased by approximately $37 \%$ in order to achieve thyrotropin levels similar to those attained in the absence of omeprazole. Sachmechi et al also showed that chronic use of PPIs (in their case lansoprazole) in hypothyroid patients resulted in statistically significant changes in thyrotropin levels which could necessitate adjustments in levothyroxine dosage (10). The drug interaction between PPIs and LT4 has also been recently reported by two epidemiological studies $(11,12)$.

The influence of $\mathrm{pH}$ on the in vitro dissolution profile of three different formulations of levothyroxine was investigated by Pabla and colleagues (13). They studied the dissolution profiles of two levothyroxine sodium tablets (Synthroid ${ }^{\circledR}$ manufactured by Abbott Laboratories, USA, and a generic product made by Sandoz Inc., USA) as well as a soft gelatin capsule (Tirosint ${ }^{\circledR}$ manufactured by IBSA Institut Biochimique, Switzerland). In general, an increase in $\mathrm{pH}$ was associated with a decrease in dissolution. When $\mathrm{pH}$ was varied from 1.2 to 8.0 , the percentage of levothyroxine that was dissolved varied drastically for Synthroid ${ }^{\circledR}$ while it remained more consistent for Tirosint ${ }^{\circledR}$. In addition, the percentages of drug that had dissolved at 30,60 and 120 minutes were different between the three formulations at increasing pHs. Overall, Tirosint ${ }^{\circledR}$ showed the highest dissolution compared to the other two formulations.

In light of the published clinical data indicating decreased levothyroxine absorption caused by PPIs, as well as in vitro results suggesting that the magnitude of the influence of $\mathrm{pH}$ on levothyroxine dissolution is formulation-dependent, the current studies were undertaken to determine the clinical impact of gastric $\mathrm{pH}$ after esomeprazole administration on the pharmacokinetics of two immediate-release levothyroxine formulations that have been shown to be bioequivalent in healthy volunteers, the soft gelatin Tirosint ${ }^{\circledR}$ capsule and the Synthroid ${ }^{\circledR}$ tablet.

\section{METHODS}

\section{Study Designs}

Data from two separate studies are presented and their designs are highlighted in Table 1 . The first one was designed to compare the pharmacokinetics of two formulations of levothyroxine (capsules and tablets) when administered under normal conditions and after the administration of a maximum of $80 \mathrm{mg}$ esomeprazole infused intravenously over 30 minutes. Subjects received either the test (capsules) or reference formulation (tablets) in a parallel group design ( 8 subjects per group). They were randomized to receive their assigned formulation with or without esomeprazole in Period 1, followed by a 45-day washout period after which levothyroxine was administered in Period 2 under the other conditions (with or without esomeprazole), in a two-way cross-over design. In the second study, the pharmacokinetic properties of the two previously tested formulations of levothyroxine (capsules and tablets) were compared head to head after the administration of $80 \mathrm{mg}$ esomeprazole infused intravenously over 30 minutes. Subjects received both test and reference formulations according to a crossover design, in which treatment administration was separated by a washout period of at least 45 days.

\section{Population}

Both studies enrolled 16 healthy male volunteers between the ages of 18 and 50 inclusively. Subjects had to weigh between 70 and $80 \mathrm{~kg}$ inclusively, with a body mass index between 18.5 and $30 \mathrm{~kg} / \mathrm{m}^{2}$ inclusively.

A total of 14 subjects from Study 1 and 15 subjects from Study 2 were evaluated. In Study 1, all men were Caucasian while in Study 2, one man $(6.7 \%)$ was of other ethnicity (Black or AfricanAmerican). Other demographic traits are summarized in Table 2, and they did not differ between groups.

Exclusion criteria included history or presence of significant diseases, history of drug, alcohol or tobacco abuse, unbalanced diet, and 
hypersensitivity or allergic reactions to the formulations ingredients or esomeprazole. Medications, including over the counter drugs, and in particular antacid agents, were not allowed from 2 weeks before screening until the end of the study. Subjects were not enrolled if they had participated in other clinical trials or donated blood in the past 3 months. Presence of Helicobacter pylori was excluded at study entry by breath test.

\section{Ethics}

The study protocols and associated documents were approved by the Ethics Committee of Canton
Ticino, Switzerland. All subjects were able to comprehend the nature of the investigation and comply with study requirements and they signed informed consent forms prior to undergoing any study-related procedures. The studies were conducted in accordance with the principles described in the Declaration of Helsinki, as well as in the ICH Harmonised Tripartite Guidelines for Good Clinical Practice.

Table 1. Study Features

\begin{tabular}{|c|c|c|}
\hline Feature & Study 1 & Study 2 \\
\hline Design & $\begin{array}{l}\text { Single-dose, open-label, randomized, two- } \\
\text { part, parallel-group }\end{array}$ & $\begin{array}{l}\text { Single-dose, open-label, randomized, two-part, } \\
\text { two-way crossover study }\end{array}$ \\
\hline Population & Healthy males & Healthy males \\
\hline Part I & $\begin{array}{l}\text { Evaluation of the variation in gastric } \mathrm{pH} \text { of } \\
\text { healthy volunteers following esomeprazole } \\
\text { infusion at a maximum dose of } 80 \mathrm{mg} \text { in } 30 \\
\text { minutes }\end{array}$ & $\begin{array}{l}\text { Evaluation of the variation in gastric } \mathrm{pH} \text { of } \\
\text { healthy volunteers following esomeprazole } \\
\text { infusion at a maximum dose of } 80 \mathrm{mg} \text { in } 30 \\
\text { minutes }\end{array}$ \\
\hline Part II & $\begin{array}{l}\text { Investigation of the pharmacokinetics of } \\
\text { levothyroxine under fasting conditions in a } \\
\text { condition of altered pH with respect to } \\
\text { normal gastric } \mathrm{pH}\end{array}$ & $\begin{array}{l}\text { Comparison of the pharmacokinetics of } \\
\text { levothyroxine of two different products } \\
\text { administered under fasting conditions and } \\
\text { increased gastric pH }\end{array}$ \\
\hline Treatments & $\begin{array}{l}\text { Subjects received either test or reference } \\
\text { product }\end{array}$ & $\begin{array}{l}\text { Subjects received both test and reference } \\
\text { products }\end{array}$ \\
\hline Test Product & $\begin{array}{l}\text { Tirosint } \AA \text { levothyroxine sodium } 150 \mu \mathrm{g} \\
\text { capsules (IBSA Institute Biochimique SA, } \\
\text { Switzerland) under fasting conditions with or } \\
\text { without prior IV infusion of esomeprazole } \\
\text { maximum } 80 \text { mg over } 30 \text { minutes }\end{array}$ & $\begin{array}{l}\text { Tirosint }{ }^{\circledR} \text { levothyroxine sodium } 150 \mu \mathrm{g} \\
\text { capsules (IBSA Institute Biochimique SA, } \\
\text { Switzerland) under fasting conditions with prior } \\
\text { IV infusion of esomeprazole maximum } 80 \mathrm{mg} \\
\text { over } 30 \text { minutes }\end{array}$ \\
\hline Reference Product & $\begin{array}{l}\text { Synthroid® levothyroxine sodium } 150 \mu \mathrm{g} \\
\text { tablets (Abbott Laboratories, USA) under } \\
\text { fasting conditions with or without prior IV } \\
\text { infusion of esomeprazole maximum } 80 \mathrm{mg} \\
\text { over } 30 \text { minutes }\end{array}$ & $\begin{array}{l}\text { Synthroid® levothyroxine sodium } 150 \mu \mathrm{g} \\
\text { tablets (Abbott Laboratories, USA) under fasting } \\
\text { conditions with prior IV infusion of } \\
\text { esomeprazole maximum } 80 \mathrm{mg} \text { over } 30 \text { minutes }\end{array}$ \\
\hline
\end{tabular}

Table 2. Subject Demographics

\begin{tabular}{cccccc}
\hline $\begin{array}{c}\text { Study } \\
\text { Number }\end{array}$ & $\begin{array}{c}\text { Formulation } \\
(\text { sample })\end{array}$ & Age (years) & Height $(\mathbf{c m})$ & Mean \pm SD (CV\%) \\
Weight $(\mathbf{k g})$ & BMI $\left(\mathbf{k g} / \mathbf{m}^{2}\right)$ \\
\hline 1 & $\begin{array}{c}\text { Capsule } \\
(\mathrm{n}=6)\end{array}$ & $33.2 \pm 6.8(20.5 \%)$ & $177.5 \pm 8.4(4.7 \%)$ & $74.6 \pm 3.4(4.5 \%)$ & $23.8 \pm 2.3(9.7 \%)$ \\
1 & $\begin{array}{c}\text { Tablet } \\
(\mathrm{n}=8)\end{array}$ & $37.1 \pm 9.2(24.7 \%)$ & $175.6 \pm 5.5(3.1 \%)$ & $74.2 \pm 2.9(3.9 \%)$ & $24.1 \pm 2.0(8.30 \%)$ \\
2 & $\begin{array}{c}\text { Tablet \& } \\
\text { Capsule (n=15) }\end{array}$ & $30.8 \pm 6.7(21.8 \%)$ & $177.7 \pm 6.0(3.4 \%)$ & $75.1 \pm 3.4(4.5 \%)$ & $23.8 \pm 1.8(7.5 \%)$ \\
\hline
\end{tabular}




\section{Treatments}

In both studies the reference formulation was 150 $\mu \mathrm{g}$ levothyroxine sodium tablets (Synthroid®; Abbott Laboratories, USA) and the test formulation was $150 \mu \mathrm{g}$ levothyroxine sodium capsules (Tirosint ${ }^{\circledR}$; IBSA Institut Biochimique SA, Switzerland). Although one is a tablet and the other one a capsule, both of these immediate-release formulations of LT4 have already been proven to be bioequivalent under fasting conditions in healthy volunteers. Single doses of $600 \mu \mathrm{g}$ of levothyroxine were administered in both studies. Esomeprazole was administered intravenously over a maximum of 30 minutes and at a maximum dose of $80 \mathrm{mg}$. The intravenous treatment was selected in order to avoid any possible interference either endogenously or exogenously in the absorption of the PPI and obtain the greatest standardization, the only variation introduced being an acute change in the intragastric $\mathrm{pH}$. With an "acute design" (that is, an acute increase in intragastric $\mathrm{pH}$ ), as opposed to a "chronic design" (that is, administration of a PPI for weeks), any clinically unapparent condition occurring over these weeks that could have affected results was avoided.

\section{Study Procedures}

At screening, which occurred between 2 to 14 days prior to the start of the study, subjects signed their informed consent forms. Eligibility was assessed based on medical history, physical examination, body weight, vital signs, electrocardiograms, laboratory results, thyroid function tests and Helicobacter pylori breath test.

During Part I of the studies, a nasogastric tube was inserted in each subject for the recording of the gastric $\mathrm{pH}$. Subjects with a mean baseline $\mathrm{pH}>2$ in the first hour (baseline) were excluded. At 8.00 a.m. $\pm 1 \mathrm{~h}$, subjects were infused the esomeprazole solution over 30 minutes for a maximum dose of 80 $\mathrm{mg}$. The $\mathrm{pH}$ was recorded for until 2 (Study 2) or 3 (Study 1) hours after the end of infusion. The nasogastric tube was then removed, and subjects left the clinical centre. Subjects who were deemed responders to esomeprazole were to be selected to continue the study with Part II. In Study 1, responders were those who had a $\mathrm{pH} \geq 4$ within 30 min of esomeprazole infusion at which time the infusion was stopped. In Study 2, subjects having a mean $\mathrm{pH} \geq 5$ during the 2 hours after the end of esomeprazole infusion were selected as responders.
In Part II of the studies, subjects were randomized to receive their treatments in Period 1 and Period 2, by means of a computer-generated randomization list. Periods were separated by a washout of 45 days. In Part II of Study 1, subjects allocated to receive the capsule treatment were administered an average dose of $75 \mathrm{mg}$ of esomeprazole, while the average dose in the tablet group was $70 \mathrm{mg}$. In Study 2, all subjects received $80 \mathrm{mg}$ esomeprazole.

On Day -1 of Periods 1 and 2, nasogastric tubes were inserted into subjects for $\mathrm{pH}$ recordings which continued until 5 hours after the administration of the investigational products. Blood samples for PK analyses were collected at $0.5,1,1.5,2,2.5,3,4,6$, $8,10,12,18$ and 24 hours post-dose. In addition, samples were collected prior to dosing to determine baseline levothyroxine levels. When esomeprazole was being administered, samples were collected before esomeprazole infusion, during the infusion (immediately after the start of the infusion for Study 1 and 15 minutes after the start of infusion for Study 2) and 3 minutes before levothyroxine dosing. In the absence of esomeprazole, samples were collected at 30,15 and 3 minutes before levothyroxine dosing for endogenous baseline characterization. Vital signs were assessed at the following times: immediately before esomeprazole infusion, before levothyroxine dosing in Study 1 (3 minutes pre-dose if esomeprazole was administered and 30 minutes pre-dose in the absence of esomeprazole), and 6, 12 and 24 hours post-dose.

On Day 2 of Period 2 after the last blood sampling, the volunteers underwent a final visit, including a complete physical examination, ECG recording and the same clinical laboratory tests performed at screening, with the exception of thyroid function tests, virology and drug screening.

Adverse events and overall wellbeing were monitored throughout the conduct of the study.

\section{Bioanalytical Assays}

For Study 1, levothyroxine concentrations in serum were determined at PharmaNet, Canada, using both a validated radioimmunoassay (RIA), with a lower quantification limit (LQL) of $1.001 \mu \mathrm{g} / \mathrm{dL}$, and a validated LC-MS/MS method, with a LQL of 0.252 $\mu \mathrm{g} / \mathrm{dL}$. Because both methods in Study 1 provided similar results only those obtained with the LCMS/MS method are presented here. For Study 2, concentrations of levothyroxine in serum were determined at PharmaNet, Canada, using a 
validated LC/MS-MS method with an LQL of 2.5 $\mu \mathrm{g} / \mathrm{dL}$.

\section{Statistical and Pharmacokinetic Analyses}

Baseline-adjusted pharmacokinetic parameters for levothyroxine that were calculated included: $\mathrm{C}_{\max }$ (maximum serum concentration), $\mathrm{T}_{\max }$ (time to achieve $\mathrm{C}_{\max }$ ), $\mathrm{AUC}_{0-\mathrm{t}}$ (Area under the concentration curve from administration to the last observed concentration time $t$, calculated with the linear trapezoidal method), $\mathrm{AUC}_{0-6}$ (Area under the concentration curve from administration to 6 hours, calculated with the linear trapezoidal method), $\mathrm{AUC}_{0-12}$ (Area under the concentration curve from administration to 12 hours, calculated with the linear trapezoidal method) and $\mathrm{F}_{\text {rel }}$ (relative bioavailability calculated as ratio $\mathrm{AUC}_{0-\mathrm{t}}$ (with infusion)/ $\mathrm{AUC}_{0-\mathrm{t}}$ (without infusion) in Study 1 and as the ratio $\mathrm{AUC}_{0-\mathrm{t}}$ test/ $\mathrm{AUC}_{0-\mathrm{t}}$ reference in Study 2).

PK parameters were calculated using baseline adjusted concentrations. For each subject, a baseline value was calculated as the arithmetic mean of all their pre-dose concentration values. Each subject's baseline value was subtracted from each post-dose concentration prior to calculation of PK parameters. Negative baseline-adjusted concentration values were treated as zero.

Analyses of variance (ANOVA) for a crossover design were performed on ln-transformed $\mathrm{PK}$ parameters $\mathrm{C}_{\max }$ and AUCs. For the comparisons (formulation + esomeprazole vs. formulation alone in Study 1, tablet + esomeprazole vs. capsule + esomeprazole in Study 2), period, treatment, sequence and subject within sequence were taken into account as sources of variability. Ratios of least square geometric means and their $90 \%$ confidence intervals (CIs) were determined from the ANOVA. Equivalence $(\mathrm{P}<0.05)$ would be indicated if the whole $90 \%$ confidence interval fell within 80.00 and 125.00 , while a difference $(\mathrm{P}<0.1)$ would be suggested if the $90 \%$ confidence interval did not include the $100 \%$ value. $\mathrm{T}_{\max }$ values were compared using the non-parametric Friedman or KruskalWallis test.

Statistical and pharmacokinetic analyses were performed using $\mathrm{SAS}{ }^{\circledR}$ version 9.1.3 service pack 4 for Windows, Bear version 2.5.3 (14) and WinNonlin version 5.2 and 6.3, Pharsight Corporation.

\section{RESULTS}

Gastric $\mathrm{pH}$ measured before and after administration of esomeprazole is displayed in Table 3. In Study 1, regardless of which levothyroxine formulation was given, in the absence of PPI infusion, the intragastric $\mathrm{pH}$ was stable in its acidity, ranging from approximately 1.0 to 2.0 . Within the first five hours of the esomeprazole infusion, the intragastric $\mathrm{pH}$ raised significantly between approximately 5.4 and 6.2. In study 2, the intragastric $\mathrm{pH}$ was approximately 1.5 before infusion and it raised to approximately 6.5 within the first five hours following the start of the esomeprazole infusion.

Following the administration of levothyroxine at normal gastric $\mathrm{pH}$, mean peak levels of approximately $5.6 \mu \mathrm{g} / \mathrm{dL}$ were reached by around 2.6 hours. When gastric $\mathrm{pH}$ was increased, maximal concentrations were decreased and were attained at around 3.5 hours. Mean baseline-adjusted concentration-time levothyroxine profiles are presented for each of the treatments tested in Figures 1 to 3 and summary statistics for pharmacokinetic parameters are presented in Table 4. Relative bioavailability parameters are presented in Table 5 while results from the ANOVA are presented in Table 6 .

Study 1 data suggested that prior administration of esomeprazole, and therefore the increase of gastric $\mathrm{pH}$, was associated with an apparent decrease in levothyroxine exposure (both rate of exposure as represented by $\mathrm{C}_{\max }$ and extent of exposure as represented by AUC). This effect was particularly evident with the tablet group where the upper limits of the $90 \%$ confidence intervals calculated for $\mathrm{C}_{\max }, \mathrm{AUC}_{0-6}$ and $\mathrm{AUC}_{0-12}$ were below $100 \%$ and the one calculated for $\mathrm{AUC}_{0-\mathrm{t}}$ only slightly above (100.81). These results therefore suggested that for the tablet, esomeprazole was associated with a statistically significant decrease in exposure $(\mathrm{P}<0.1)$. The mean $\mathrm{C}_{\max }$ of levothyroxine appeared to decrease on average by $6 \%$ for the capsules $(\mathrm{P}=\mathrm{NS})$, and by approximately $13 \%$ for the tablets when esomeprazole was co-administered $(\mathrm{P}<0.1)$. A similar trend was noted for the overall and partial exposures, where the decrease caused by esomeprazole on $\mathrm{AUC}_{0-\mathrm{t}}$ and $\mathrm{AUC}_{0-6}$ appeared to be slightly greater with the tablet (10 and 18\%) than with the capsule ( 8 and 14\%), and was only statistically decreased for the tablet $(\mathrm{P}<0.1)$. 


\begin{tabular}{|c|c|c|c|c|c|c|}
\hline \multirow[b]{2}{*}{ Assessment Period } & \multirow{2}{*}{$\begin{array}{c}\begin{array}{c}\text { Study } 1 \\
\text { Tablet } \\
(\mathrm{n}=8)\end{array} \\
\end{array}$} & \multirow[b]{2}{*}{$\begin{array}{c}\text { Study } 1 \\
\text { Tablet }+ \\
\text { esomeprazole } \\
(\mathbf{n}=\mathbf{8})\end{array}$} & \multicolumn{2}{|c|}{ Mean \pm SD $(C V \%)$} & \multirow[b]{2}{*}{$\begin{array}{c}\text { Study } 2 \\
\text { Tablet }+ \\
\text { esomeprazole } \\
(n=15)\end{array}$} & \multirow[b]{2}{*}{$\begin{array}{c}\text { Study } 2 \\
\text { Capsule }+ \\
\text { esomeprazole } \\
(n=15)\end{array}$} \\
\hline & & & $\begin{array}{c}\text { Study } 1 \\
\text { Capsule } \\
(n=6)\end{array}$ & $\begin{array}{c}\text { Study } 1 \\
\text { Capsule }+ \\
\text { esomeprazole } \\
(n=6)\end{array}$ & & \\
\hline Before infusion & - & $\begin{array}{c}1.74 \pm 1.42 \\
(81.7 \%)\end{array}$ & - & $\begin{array}{c}1.95 \pm 1.52 \\
(77.7 \%)\end{array}$ & $\begin{array}{l}1.3 \pm 1.1 \\
(84.6 \%)\end{array}$ & $\begin{array}{l}1.6 \pm 1.2 \\
(75.0 \%)\end{array}$ \\
\hline $\begin{array}{l}0-2 \mathrm{~h} \text { after levothyroxine } \\
\text { administration }\end{array}$ & $\begin{array}{c}0.99 \pm \\
0.81 \\
(82.2 \%)\end{array}$ & $\begin{array}{l}6.19 \pm 1.05 \\
(17.0 \%)\end{array}$ & $\begin{array}{c}2.11 \pm \\
1.50 \\
(71.0 \%)\end{array}$ & $\begin{array}{l}5.76 \pm 1.60 \\
(27.8 \%)\end{array}$ & $\begin{array}{l}6.4 \pm 0.9 \\
(14.1 \%)\end{array}$ & $\begin{array}{l}6.6 \pm 1.0 \\
(15.2 \%)\end{array}$ \\
\hline $\begin{array}{l}0-5 \mathrm{~h} \text { after levothyroxine } \\
\text { administration }\end{array}$ & $\begin{array}{c}1.09 \pm \\
0.99 \\
(90.9 \%)\end{array}$ & $\begin{array}{l}5.63 \pm 1.37 \\
(24.3 \%)\end{array}$ & $\begin{array}{c}2.10 \pm \\
1.74 \\
(82.8 \%)\end{array}$ & $\begin{array}{l}5.43 \pm 1.41 \\
(26.0 \%)\end{array}$ & $\begin{array}{l}6.0 \pm 1.0 \\
(16.7 \%)\end{array}$ & $\begin{array}{c}6.3 \pm 1.2 \\
(19.0 \%)\end{array}$ \\
\hline
\end{tabular}

Table 6. Ratios and 90\% Confidence Intervals for Comparisons of Interest

\begin{tabular}{|c|c|c|c|c|}
\hline Study & Comparison & PK Parameter & Ratio & $90 \% \mathrm{CI}$ \\
\hline \multirow[t]{4}{*}{1} & Capsule + esomeprazole & $\operatorname{Cmax}(\mu \mathrm{g} / \mathrm{dL})$ & $94.28 \%$ & $73.36 \%-121.16 \%$ \\
\hline & \multirow{3}{*}{$\begin{array}{c}\text { vs } \\
\text { Capsule alone }\end{array}$} & $\operatorname{AUC}_{0-6}(\mu \mathrm{g} * \mathrm{~h} / \mathrm{dL})$ & $86.38 \%$ & $70.87 \%-105.28 \%$ \\
\hline & & $\operatorname{AUC}_{0-12}(\mu \mathrm{g} * \mathrm{~h} / \mathrm{dL})$ & $94.91 \%$ & $76.55 \%-117.67 \%$ \\
\hline & & $\mathrm{AUC}_{0-\mathrm{t}}\left(\mu \mathrm{g}^{*} \mathrm{~h} / \mathrm{dL}\right)^{\dagger}$ & $92.18 \%$ & $71.21 \%-119.34 \%$ \\
\hline \multirow[t]{4}{*}{1} & \multirow{4}{*}{$\begin{array}{c}\text { Tablet }+ \text { esomeprazole } \\
\text { vs } \\
\text { Tablet alone }\end{array}$} & $\operatorname{Cmax}(\mu \mathrm{g} / \mathbf{d L})$ & $87.32 \%$ & $79.63 \%-95.76 \%$ \\
\hline & & $\operatorname{AUC}_{0-6}(\mu \mathrm{g} * \mathrm{~h} / \mathrm{dL})$ & $82.26 \%$ & $70.15 \%-96.45 \%$ \\
\hline & & $\operatorname{AUC}_{0-12}\left(\mu g^{*} h / d L\right)$ & $83.22 \%$ & $72.85 \%-95.06 \%$ \\
\hline & & $\operatorname{AUC}_{0-\mathrm{t}}(\mu \mathrm{g} * \mathrm{~h} / \mathrm{dL})^{\dagger}$ & $89.61 \%$ & $79.65 \%-100.81 \%$ \\
\hline \multirow[t]{4}{*}{2} & \multirow{4}{*}{$\begin{array}{c}\text { Tablet }+ \text { esomeprazole } \\
\text { vs } \\
\text { Capsule }+ \text { esomeprazole }\end{array}$} & $\operatorname{Cmax}(\mu \mathrm{g} / \mathrm{dL})$ & $83.81 \%$ & $72.27 \%-97.19 \%$ \\
\hline & & $\operatorname{AUC}_{0-6}\left(\mu g^{*} \mathbf{h} / \mathbf{d L}\right)$ & $84.04 \%$ & $71.71 \%-98.49 \%$ \\
\hline & & $\operatorname{AUC}_{0-12}\left(\mu g^{*} h / d L\right)$ & $85.17 \%$ & $73.48 \%-98.72 \%$ \\
\hline & & $\mathrm{AUC}_{0-\mathrm{t}}(\mu \mathrm{g} * \mathrm{~h} / \mathrm{dL})^{\dagger}$ & $84.38 \%$ & $70.87 \%-100.47 \%$ \\
\hline
\end{tabular}

Note: Results in bold suggest statistically significant difference at $\mathrm{P}<0.1$

${ }^{\dagger}$ The last detectable concentration for all subjects was measured at 24 hours post-dose.

For all subjects, a rise in serum concentrations of levothyroxine was noted between 12 and 24 hours post-dose, an observation hypothesized to result from endogenous levothyroxine being secreted again more than 12 hours after the single dose administration of $600 \mathrm{mcg}$. Because of the potential for this feedback to affect the results, the baseline adjusted AUC was calculated from time zero to 12 hours. For this partial AUC, the decrease associated with the tablet was approximately $17 \%$ in the esomeprazole group while it was only around 5\% for the capsule.

The apparent differences in exposure associated with each formulation are also reflected in the relative bioavailability estimates as that of the capsule formulation (in the presence of esomeprazole compared to administration without the PPI) was approximately $98 \%$ while it was approximately $91 \%$ for the tablet formulation.

Under conditions of increased gastric $\mathrm{pH}$ (after esomeprazole administration), exposure from the tablet formulation appears to be generally less than that of the capsule formulation. The comparison performed in Study 2 demonstrated that levothyroxine peak exposure with the tablet is $16 \%$ smaller than with the capsule after esomeprazole administration. In Study 2, 90\% confidence intervals for all the maximum (Cmax) and partial exposure $\left(\mathrm{AUC}_{0-6}, \mathrm{AUC}_{0-12}\right) \mathrm{PK}$ parameters were outside the generally accepted interval of 80 to $125 \%$ and did not contain $100 \%$, suggesting a statistical difference at $\mathrm{p}<0.1$. At all time points between 1 and $24 \mathrm{~h}$, mean serum levothyroxine values were higher for the capsules than for the 


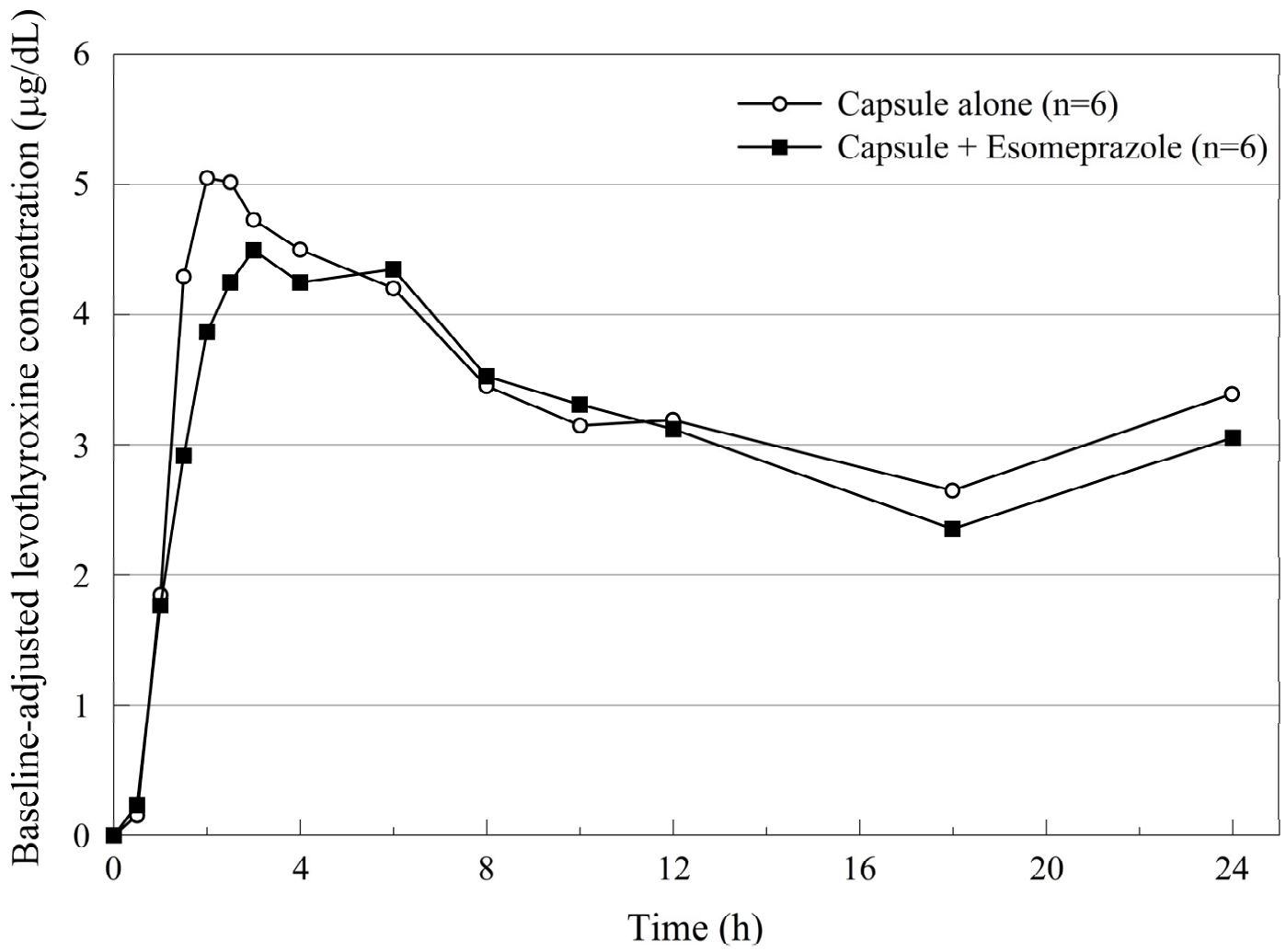

Figure 1. Mean baseline-adjusted levothyroxine concentration time profile for capsule formulation in Study 1 (crossover comparison).

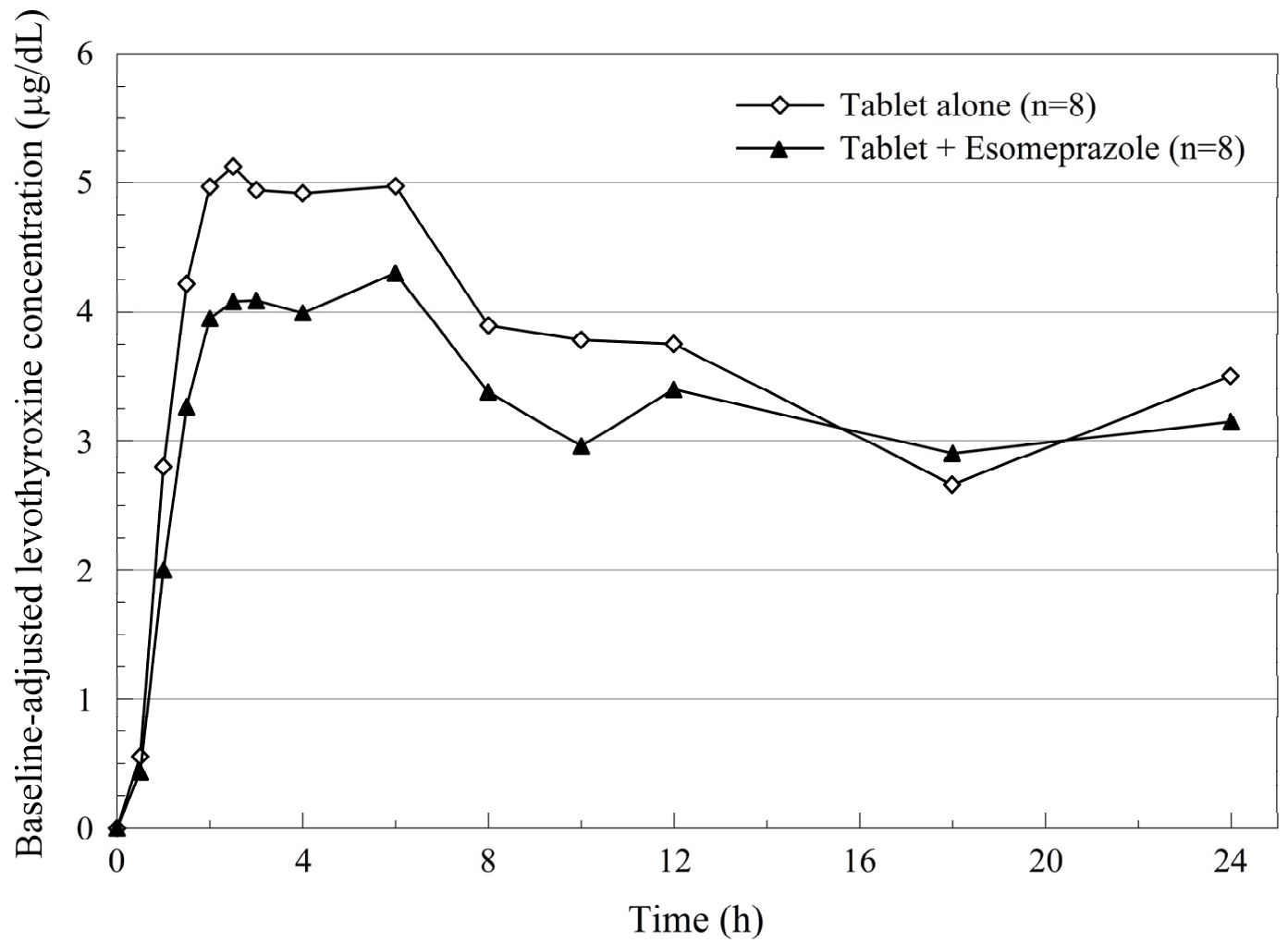


Figure 2. Mean baseline-adjusted levothyroxine concentration time profile for tablet formulation in Study 1 (crossover comparison).

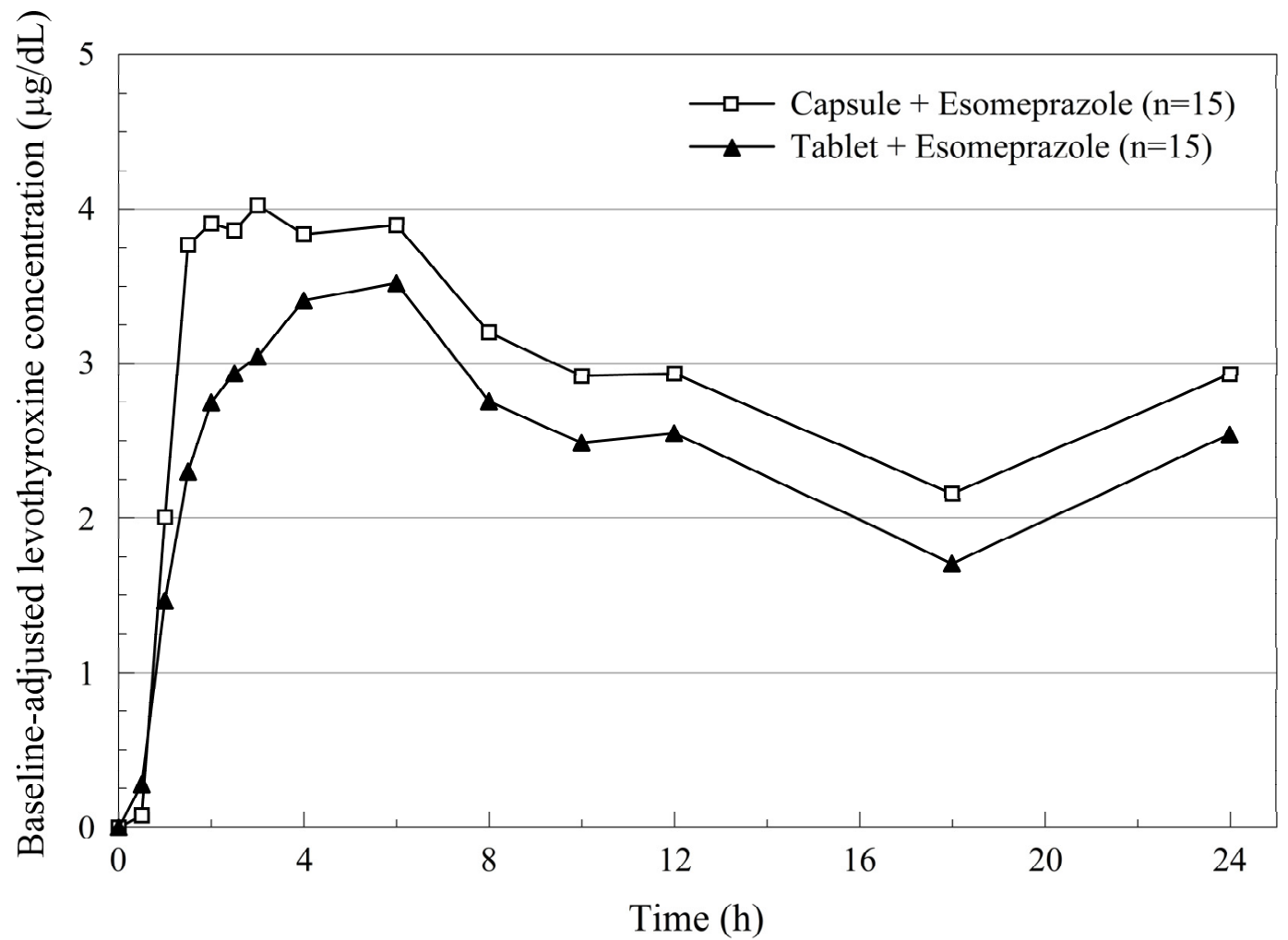

Figure 3. Mean baseline-adjusted levothyroxine concentration time profile for capsule and tablet formulations with esomeprazole in Study 2 (crossover comparison).

tablets and perfect parallelism between the two concentration-time curves appeared to exist from 4 $\mathrm{h}$ on, suggesting that the biggest difference between the tablet and the capsule occurred during the first 4 hours after levothyroxine and concomitant esomeprazole administrations. In Study 1, $\mathrm{T}_{\max }$ values were not significantly affected by esomeprazole co-administration for both capsules and tablets $(\mathrm{p}=\mathrm{NS})$. In Study 2, where a crossover design was used, a trend toward statistical significance $(\mathrm{P}=0.05)$ was seen with an apparent faster absorption with the capsule $\left(\mathrm{T}_{\max }=3 \mathrm{~h}\right)$ than with the tablet $\left(\mathrm{T}_{\max }=4 \mathrm{~h}\right)$.

\section{DISCUSSION}

Study 1 was designed to investigate the pharmacokinetics and the bioavailability of levothyroxine after the administration of two different products to healthy male volunteers under fasting conditions and in a condition of altered $\mathrm{pH}$ with respect to normal gastric $\mathrm{pH}$. Because the findings from this study demonstrated that gastric
$\mathrm{pH}$ influenced levothyroxine absorption, Study 2 was conducted to further quantify the potential differences between the absorption of tablet and soft gel capsule formulations of levothyroxine under modified gastric $\mathrm{pH}$ conditions. In the first study, different cohorts received the tablets and soft gel capsules, therefore it was more difficult to directly compare the results of each formulation under modified gastric $\mathrm{pH}$ conditions. Thus, a crossover design was used in Study 2 to ensure that any differences noted between treatments could truly be attributed to differences in formulations as opposed to differences between subjects.

To the best of our knowledge, the studies described herein are the first published accounts comparing the in vivo influence of increased gastric acid $\mathrm{pH}$ induced by esomeprazole on the pharmacokinetics of two immediate-release formulations of levothyroxine that have been previously shown to be bioequivalent under fasting conditions. The findings of our analyses confirm the in vitro dissolution results established by Pabla and colleagues (13), who suggested that levothyroxine 
soft gel capsules may be less sensitive to the influence of $\mathrm{pH}$ increases than tablets. Although both levothyroxine capsules and tablets were associated with a potential decrease in exposure in the presence of increased gastric $\mathrm{pH}$, the magnitude of the decrease appeared larger and was only statistically significant for the tablet formulation. When esomeprazole was administered prior to levothyroxine, the overall relative bioavailability of the capsule formulation appeared to be relatively unchanged ( $2 \%$ decrease) while it appeared to decrease slightly by $9 \%$ for the tablet.

The decreased levothyroxine exposure associated with increased gastric $\mathrm{pH}$ that was noted in our analyses for the tablet was similar to decreases reported by others in healthy volunteers. Dietrich et al. studied the influence of $40 \mathrm{mg}$ daily oral pantoprazole (given for 1 week) on the pharmacokinetics of levothyroxine (Euthyrox ${ }^{\circledR}$, Merck KgaA, Darmstadt, Germany) in a group of 20 healthy euthyroid volunteers composed of 11 females and 9 males (15). Blood samples were collected over 10 hours post-dose and PK parameters such as $\mathrm{C}_{\max }$ and $\mathrm{AUC}_{0-\mathrm{t}}$ were determined for $\mathrm{TSH}, \mathrm{T} 4$ and free thyroxine equivalents. Similarly to our results, T4 exposure decreased when pantoprazole was used prior to levothyroxine administration. The $\mathrm{C}_{\max }$ of $\mathrm{T} 4$ decreased in the presence of pantoprazole, by approximately $21 \%(\mathrm{p}=0.02)$. These results are in agreement with our findings of apparent decreased levothyroxine exposure in the presence of a PPI. On the other hand, another study evaluating the effect of esomeprazole on the pharmacokinetics of levothyroxine tablets (Synthroid $\AA$ ) in healthy volunteers (in 4 men and 6 women) did not show or suggest a decrease in either unadjusted or baselinecorrected $\mathrm{C}_{\max }$ or $\mathrm{AUC}_{0-8}$ (16). In that particular study, $40 \mathrm{mg}$ esomeprazole was administered daily for 1 week prior to the administration of $600 \mu \mathrm{g}$ of levothyroxine tablets. Mean estimates for $\mathrm{C}_{\max }$ and AUC were similar regardless of the administration of esomeprazole. It is apparent from our study that the effect of the PPI on levothyroxine tablets is much more pronounced in the first two hours after dosing, but in the study with the negative results the profiles were created with only 5 samples, with the first post dose sample taken at 2 hours, so it is possible that the effect was missed.

The interaction between PPIs and levothyroxine was also documented clinically in hypothyroid patient populations $(9,10)$, by measuring changes in
TSH levels. All studies demonstrate a similar trend with respect to the influence of PPIs on levothyroxine. The increase in gastric $\mathrm{pH}$ associated with PPIs leads to decreased exposure of levothyroxine, as shown by our findings, which in turn modulates the feedback loop that maintains T4 homeostasis, leading to increased levels of TSH as demonstrated by Centanni and Sachmechi $(9,10)$.

The sample size associated with this analysis was relatively small, nevertheless the findings described herein contribute to our knowledge on levothyroxine absorption. The potentially greater exposure of levothyroxine capsules compared to levothyroxine tablets under conditions of increased gastric $\mathrm{pH}$ induced by esomeprazole could prove to be beneficial for patients. In theory, hypothyroid patients treated with levothyroxine capsules, rather than tablets, may experience smaller variations in hormone levels if they experienced impaired secretion of gastric acid or took medication that modified gastric $\mathrm{pH}$. These conditions may be transitory during the life of the patient and may therefore lead to fluctuations of TSH and to transitory undertreatment. In a published case report, a hypothyroid woman who was taking proton pump inhibitors and who failed to be normalized by levothyroxine administered in the form of a tablet was instead normalized when switched to the capsule (17). A recent study conducted in patients with impaired gastric acid secretion, demonstrated that lower doses of levothyroxine were required to maintain the therapeutic goal when administered in the capsule formulation with respect to a tablet (18).

In addition, this study provides a clinical situation for which proving therapeutic equivalence or PK equivalence in healthy volunteers may not translate to $\mathrm{PK}$ equivalence in patients, more particularly those with impaired gastric $\mathrm{pH}$, and is an additional proof of the interaction of PPIs on drug absorption. A study conducted in rats who were administered meloxicam also suggests that formulations that are deemed bioequivalent under healthy conditions might not be bioequivalent in disease conditions, such as pain or its associated trauma (19). Rats were administered two different oral formulations of meloxicam (brand and fast dissolving) and in one cohort, intraperitoneal propantheline was used to suppress the vagus nerve and decrease gastric fluid secretion and motility. In the control group, the two formulations of meloxicam were deemed equivalent in terms of rate 
and extent of exposure (Cmax and $\left.\mathrm{AUC}_{0-24}\right)$, while in the vagally suppressed rats, equivalence could not be concluded because absorption of the brand product was decreased by more than $50 \%$ compared to the healthy state. Although these results were obtained in rats, meloxicam appears to have similar pharmacokinetics in rats and in humans, therefore these findings could be extrapolated to humans, suggesting that bioequivalence may be diseasedependent.

\section{CONCLUSION}

Levothyroxine appears to have a decreased exposure when gastric $\mathrm{pH}$ is modified by i.v. administration of esomeprazole, but the decrease appears to be less important or null for the capsules compared to the tablets, even though these two immediate-release formulations have previously been shown to be bioequivalent in healthy volunteers under fasting conditions. The current in vivo results obtained in healthy subjects appear to confirm previously published in vitro findings, and are also similar to clinical observations made in hypothyroid patients. Levothyroxine maximum and partial exposure from soft gel capsules appear to be less affected by decreased gastric $\mathrm{pH}$ than a commercialized tablet reference formulation, and may therefore be a more advantageous formulation for some patients who suffer from malabsorption problems related to decreased gastric acidity. In addition, the current study provides an example of two immediate-release formulations, a capsule and a tablet, that have been demonstrated to be bioequivalent under fasting conditions in healthy volunteers but that may not necessarily be bioequivalent in patient populations with impaired gastric acidity.

\section{ACKNOWLEDGMENTS}

These studies were funded by IBSA Institut Biochimique SA., Switzerland.

\section{REFERENCES}

1. Almandoz JP, Gharib H. Hypothyroidism: etiology, diagnosis, and management. The Medical clinics of North America, 2012; 96:203-221.

2. Vanderpump MP. The epidemiology of thyroid disease. Br Med Bull, 2011; 99:39-51.

3. Garmendia Madariaga A, Santos Palacios S, Guillen-Grima F, Galofre JC. The incidence and prevalence of thyroid dysfunction in Europe: a metaanalysis. The Journal of clinical endocrinology and metabolism, 2014; 99:923-931.

4. Colucci P, D'Angelo P, Mautone G, Scarsi C, Ducharme MP. Pharmacokinetic equivalence of a levothyroxine sodium soft capsule manufactured using the new food and drug administration potency guidelines in healthy volunteers under fasting conditions. Therapeutic drug monitoring, 2011; 33:355-361.

5. Colucci P, Seng Yue C, Ducharme MP, Benvenga S. A Review of the Pharmacokinetics of Levothyroxine for the Treatment of Hypothyroidism. European Endocrinology, 2013; 9:40-47.

6. Benvenga $\mathrm{S}$. When thyroid hormone replacement is ineffective? Current Opinion in Endocrinology, Diabetes \& Obesity, 2013; 20:467-477.

7. Liwanpo L, Hershman JM. Conditions and drugs interfering with thyroxine absorption. Best Practice \& Research Clinical Endocrinology \& Metabolism, 2009; 23:781-792.

8. U.S. National Library of Medicine, National Institutes of Health. NEXIUM- esomeprazole magnesium granule, delayed release http://dailymed.nlm.nih.gov/dailymed/drugInfo.cfm? setid=f4853677-1622-4037-688b-fdf533a11d96, 2015.

9. Centanni M, Gargano L, Canettieri G, Viceconti N, Franchi A, Delle Fave G, Annibale B. Thyroxine in goiter, Helicobacter pylori infection, and chronic gastritis. The New England journal of medicine, 2006; 354:1787-1795

10. Sachmechi I, Reich DM, Aninyei M, Wibowo F, Gupta G, Kim PJ. Effect of proton pump inhibitors on serum thyroid-stimulating hormone level in euthyroid patients treated with levothyroxine for hypothyroidism. Endocrine practice : official journal of the American College of Endocrinology and the American Association of Clinical Endocrinologists, 2007; 13:345-349.

11. S AI, Vadiveloo T, Leese GP. Drugs that interact with levothyroxine: an observational study from the Thyroid Epidemiology, Audit and Research Study (TEARS). Clinical endocrinology, 2015; 82:136141.

12. Trifiro G, Parrino F, Sultana J, Giorgianni F, Ferrajolo C, Bianchini E, Medea G, Benvenga S, Cricelli I, Cricelli C, Lapi F. Drug interactions with levothyroxine therapy in patients with hypothyroidism: observational study in general practice. Clinical drug investigation, 2015; 35:187195.

13. Pabla D, Akhlaghi F, Zia H. A comparative pHdissolution profile study of selected commercial levothyroxine products using inductively coupled plasma mass spectrometry. European journal of 
pharmaceutics and biopharmaceutics, 2009; 72:105110.

14. Lee H, Lee Y. Bear. 2.5.3 ed, 2014; Kaohsiung City, Taiwan.

15. Dietrich JW, Gieselbrecht K, Holl RW, Boehm BO. Absorption kinetics of levothyroxine is not altered by proton-pump inhibitor therapy. Hormone and metabolic research, 2006; 38:57-59.

16. Ananthakrishnan S, Braverman LE, Levin RM, Magnani B, Pearce EN. The effect of famotidine, esomeprazole, and ezetimibe on levothyroxine absorption. Thyroid, 2008; 18:493-498.

17. Vita R, Benvenga S. Tablet levothyroxine (L-T4) malabsorption induced by proton pump inhibitor; a problem that was solved by switching to L-T4 in soft gel capsule. Endocrine practice, 2014; 20:e38-41.

18. Santaguida MG, Virili C, Del Duca SC, Cellini M, Gatto I, Brusca N, De Vito C, Gargano L, Centanni M. Thyroxine softgel capsule in patients with gastric-related T4 malabsorption. Endocrine, 2015; 49:51-57.

19. Aghazadeh-Habashi A, Jamali F. Pharmacokinetics of meloxicam administered as regular and fast dissolving formulations to the rat: Influence of gastrointestinal dysfunction on the relative bioavailability of two formulations. European Journal of Pharmaceutics and Biopharmaceutics, 2008; 70: 889-894. 


\begin{tabular}{|c|c|c|c|c|c|c|}
\hline \multirow{2}{*}{$\begin{array}{c}\text { PK } \\
\text { Parameter } \\
\text { Mean } \pm \text { SD } \\
(\mathrm{CV} \%)\end{array}$} & \multicolumn{2}{|c|}{ Normal gastric pH - Study 1} & \multicolumn{2}{|c|}{ With Esomeprazole - Study 1} & \multicolumn{2}{|c|}{ With Esomeprazole - Study 2} \\
\hline & Capsule $(n=6)$ & Tablet $(n=8)$ & Capsule $(n=6)$ & Tablet $(n=8)$ & Tablet & Capsule $(n=15)$ \\
\hline $\begin{array}{l}\text { Cmax } \\
(\mu \mathrm{g} / \mathrm{dL})\end{array}$ & $5.68 \pm 2.07(36.4)$ & $5.54 \pm 1.16(21.0 \%)$ & $\begin{array}{c}5.53 \pm 1.81(32.8 \%) \\
-0.15[-2.6 \%]\end{array}$ & $\begin{array}{c}4.82 \pm 0.94(19.5 \%) \\
-0.72[-13.0 \%]\end{array}$ & $\begin{array}{l}3.75 \pm 0.663(17.7 \%) \\
-0.88[-19.0 \%]\end{array}$ & $4.63 \pm 1.48(31.9 \%)$ \\
\hline $\begin{array}{l}\text { Tmax* } \\
\text { (h) }\end{array}$ & $2.50(1.50-4.00)$ & $2.75(1.50-6.00)$ & $\begin{array}{l}3.00(1.50-6.00) \\
\quad+0.5[+20 \%]\end{array}$ & $\begin{array}{c}3.50(1.50-8.00)+0.75 \\
{[+27 \%]}\end{array}$ & $\begin{array}{l}4.00(2.00-6.00) \\
+1.0[+33.3 \%]\end{array}$ & $3.00(1.50-6.00)$ \\
\hline $\begin{array}{l}\mathrm{AUC}_{0-\mathrm{t}}^{\dagger} \\
\left(\mu \mathrm{g}^{*} \mathrm{~h} / \mathrm{dL}\right)\end{array}$ & $78.9 \pm 15.8(20.1 \%)$ & $86.7 \pm 16.2(18.7 \%)$ & $\begin{array}{c}74.4 \pm 14.2(19.1 \%) \\
-4.5[-5.7 \%]\end{array}$ & $\begin{array}{c}77.6 \pm 13.6(17.5 \%) \\
-9.1[-10.5 \%]\end{array}$ & $\begin{array}{c}57.9 \pm 14.6(25.2 \%) \\
-11.2[-16.2 \%]\end{array}$ & $69.1 \pm 19.1(27.6 \%)$ \\
\hline $\begin{array}{l}\mathrm{AUC}_{0-12} \\
(\mu \mathrm{g} * \mathrm{~h} / \mathrm{dL})\end{array}$ & $43.2 \pm 10.1(23.4 \%)$ & $49.0 \pm 10.2(20.8 \%)$ & $\begin{array}{c}41.7 \pm 7.61(18.2 \%) \\
-15.0[3.5 \%]\end{array}$ & $\begin{array}{c}40.6 \pm 7.32(18.0 \%) \\
-84.0[17.1 \%]\end{array}$ & $\begin{array}{l}32.3 \pm 7.01(21.7 \%) \\
-6.30[-16.3 \%]\end{array}$ & $38.6 \pm 10.4(26.9 \%)$ \\
\hline $\begin{array}{l}\mathrm{AUC}_{0-6} \\
\left(\mu \mathrm{g}^{*} \mathrm{~h} / \mathrm{dL}\right)\end{array}$ & $22.7 \pm 5.8(25.8 \%)$ & $24.9 \pm 5.9(23.6 \%)$ & $\begin{array}{l}20.6 \pm 5.5(26.7 \%) \\
-2.1[-9.3 \%]\end{array}$ & $\begin{array}{l}20.2 \pm 3.5(17.5 \%) \\
\quad-4.7[-18.9 \%]\end{array}$ & $\begin{array}{l}15.8 \pm 3.1(19.7 \%) \\
\quad-3.7[-19.0 \%]\end{array}$ & $19.5 \pm 6.2(32.1 \%)$ \\
\hline
\end{tabular}

*Median (range)

${ }^{\dagger}$ The last detectable concentration for all subjects was measured at 24 hours post-dose.

Note: Values in italics represent the absolute difference of mean (median for Tmax) [percentage relative difference] between the values associated with the concomitant use of esomeprazole and the values under normal $\mathrm{pH}$ conditions (for Study 1) and for the difference between the tablet and the capsule (Study 2 ).

\begin{tabular}{|c|c|c|c|}
\hline Statistic & $\begin{array}{l}\text { Capsule + esomeprazole vs. } \\
\text { Capsule alone } \\
\text { (Study 1) }\end{array}$ & $\begin{array}{l}\text { Tablet + esomeprazole vs. } \\
\text { Tablet alone } \\
\text { (Study 1) }\end{array}$ & $\begin{array}{l}\text { Tablet + esomeprazole vs. } \\
\text { Capsule + esomeprazole } \\
\quad \text { (Study 2) }\end{array}$ \\
\hline $\mathrm{N}$ & 6 & 8 & 15 \\
\hline Arithmetic Mean & 97.51 & 91.01 & 90.02 \\
\hline Standard Deviation & \pm 29.45 & \pm 16.93 & \pm 32.90 \\
\hline $\mathrm{CV} \%$ & 30.21 & 18.60 & 36.5 \\
\hline \multicolumn{4}{|c|}{$\begin{array}{l}\text { Note: For Study } 1 \text {, relative bioavailability was calculated as the ratio of } \mathrm{AUC}_{0-\mathrm{t}} \text { when levothyroxine was given with esomeprazole relative to } \mathrm{AUC}_{0-\mathrm{t}} \text { when } \\
\text { levothyroxine was given without esomeprazole. For Study } 2 \text {, relative bioavailability was calculated as the ratio of } A U C_{0-\mathrm{t}} \text { for the tablet (with esomeprazole) over } \\
\mathrm{AUC}_{0-\mathrm{t}} \text { for the capsule (with esomeprazole). }\end{array}$} \\
\hline
\end{tabular}

